\title{
CTAG1A Gene
}

National Cancer Institute

\section{Source}

National Cancer Institute. CTAG1A Gene. NCI Thesaurus. Code C81879.

This gene may be involved in both testis development and spermatogenesis. 